al. A recurrent outbreak of nosocomial legionnaires' disease detected by urinary antigen testing: evidence for long-term colonization of a hospital plumbing system. Infect Control Hosp Epidemiol 1998:19:905-910.

10. Centers for Disease Control and Prevention. Sustained transmission of nosocomial legionnaires' disease-Arizona and Ohio. MMWR 1997;46:416-421.

11. Kool JL, Fiore AE, Kioski CM, Brown EW, Benson RF, Pruckler JM, et al. More than 10 years of unrecognized nosocomial transmission of legionnaires' disease among transplant patients. Infect Control Hosp Epidemiol 1998;19:898-904.

12. Allegheny County Health Department. Approaches to prevention and control of Legionella infection in healthcare facilities. Pittsburgh, PA. Allegheny County Health Department; 1993.

13. Centers for Disease Control and Prevention. Guideline for prevention of nosocomial pneumonia. $M M W R$ 1997:46(RR-1):28-34,54-57,74-79.

14. Gaynes R. Impact of the National Nosocomial Infections Surveillance (NNIS) System on the surveillance of nosocomial infections. Infect Control Hospital Epidemiol 1997;18(suppl):20.

15. Edelstein PH. Legionnaires' disease. Clin Infect Dis 1993;16:741-749.

16. Mandel AS, Sprauer MA, Sniadack DH, Ostroff SM. State regulation of hospital water temperature. Infect Control Hosp Epidemiol 1993;14:642-645.

17. Alary M, Joly JR. Factors contributing to the contamination of hospital water distribution systems by Legionella. J Infect Dis 1992;165:565-569.

18. Brundrett GW. Surveys of Legionella in building services not associated with outbreaks. In: Legionella and Building Services. Oxford, England: Butterworth-Heinemann Ltd; 1992:167-189.

19. Landeen LK, Yahya MT, Gerba CP. Efficacy of copper and silver ions and reduced levels of free chlorine in inactivation of Legionella pneumophila. Appl Environ Microbiol 1989;55:3045-3050.

20. Liu Z, Stout JE, Tedesco L, Boldin M, Hwang C, Diven WF, et al. Controlled evaluation of copper-silver ionization in eradicating Legionella pneumophila from a hospital water distribution system. $J$ Infect Dis 1994;169:919-922.

21. Miuetzner S, Schwille RC, Farley A, Wald ER, Ge JH, States SI, et al. Efficacy of thermal treatment and copper-silver ionization for controlling Legionella pneumophila in high-volume hot water plumbing systems in hospitals. Am J Infect Control 1997;25:452-457.

22. Stout JE, Lin Y-SE, Goetz AM, Muder RR. Controlling Legionella in hospital water systems: experience with the superheat-and-flush method and copper-silver ionization. Infect Control Hosp Epidemiol 1998;19:911-914.

23. Liu Z, Stout JE, Boldin M, Rugh J, Diven WF, Yu VL. Intermittent use of copper-silver ionization for Legionella control in water distribution systems: a potential option in buildings housing individuals at low risk of infection. Clin Infect Dis 1998;26:138-140.

\title{
Efficacy of Silver-Coating Central Venous Catheters
}

\section{Gina Pugliese, RN, MS Martin S. Favero, PhD}

Bach and coinvestigators from the University of Heidelberg compared silver-coated and uncoated double-lumen central venous catheters in a prospective, randomized, clinical trial among ICU patients after cardiac surgery.

Sixty-seven adult patients were prospectively randomized to receive either a silver-coated ( $S$ group, $n=34$ ) or an uncoated control (C group, $\mathrm{n}=33$ ) DLC. Blood cultures were drawn at catheter removal, and removed catheters were analyzed with quantitative cultures of three segments: the catheter tip, an intermediate section, and the subcutaneous portion. The frequency of colonization of at least one catheter segment was $52.9 \%$ for the silver-coated catheters and $57.6 \%$ for the control catheters $(P=.44)$, without any significant differences in the colonization of corresponding catheter segments. Lower colony counts were found with the silver-coated catheters, but the difference was not significant. Pattern analysis after PFGE demonstrated that approximately $70 \%$ of the isolates found on the catheter tip were identical with those on the skin at the insertion site, whereas approximately $75 \%$ were identical with those recovered from the hub. In $29 \%$ of colonized catheters, identical bacteria were found on the hub and the skin at the insertion site.

It was concluded that silvercoating did not significantly reduce bacterial catheter colonization. The skin around the insertion site must be regarded as the main source of organisms involved in catheter-related infections.

FROM: Bach A, Eberhardt $\mathrm{H}$, Frick A, Schmidt $H$, Bottiger BW, Martin E. Efficacy of silver-coating central venous catheters in reducing bacterial colonization. Crit Care Med 1999;27:515-521. 